\title{
Hubungan antara Dukungan Emosional Orangtua dan Agresivitas Remaja dengan Orangtua Bercerai
}

\author{
Dita Ridho Saqinah ${ }^{1}$, Siti Suminarti Fasikhah ${ }^{2}$, U'un Zulfiana ${ }^{3}$ \\ Fakultas Psikologi, Universitas Muhammadiyah Malang

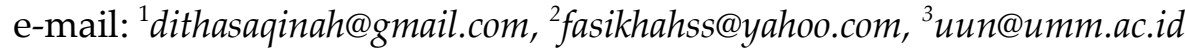

\begin{abstract}
The emergence of aggressive behavior in teenagers can occur due to various factors, the family is one important aspect that is allegedly associated with the pattern adolescent aggressive behavior. The role of parents to adolescent aggressive behavior by providing emotional support needed to suppress aggressive behavior in adolescents themselves. The purpose of this study was to investigate the relationship between emotional support of parents and the aggressiveness of adolescents with divorced parents. The sampling technique used purposive technique with a subjects were 113 boys and girls with divorced parents aged 12 to 22 years, and lived with one parent. This research instruments using Agression Questionnair scale and the scale of parental emotional support made by the author based on aspects of emotional support by Thoits 1986 with data analysis using SPSS 21. The results show the value of $(r)$ of -0.327 with $p 0.000<0$, 05. It shows that there is a significant negative correlation between parental emotional support and aggressiveness of adolescents with divorced parents. Parental emotional support's contribution to adolescents with divorced parents aggressiveness of $10.7 \%$ ( $r 2=$ 0.107)
\end{abstract}

KEYWORDS Parental emotional support, aggressiveness, adolescent, divorce

CITATION Saqinah, D., Fasikhah, S., \& Zulfiana, U. (2019). Hubungan antara dukungan emosional orangtua dan agresivitas remaja dengan orangtua bercerai. Cognicia, 7, (2), 258-269.

Tempat perkembangan awal bagi seorang anak sejak saat kelahirannya hingga proses perkembangan jasmani dan rohani di masa mendatang adalah keluarga. Mereka membutuhkan kasih sayang, perhatian, dan rasa aman untuk berlindung pada orangtuanya untuk mencapai perkembangannya. Tanpa sentuhan manusiawi itu, anak akan merasa terancam dan dipenuhi rasa takut. Bagi seorang anak, keluarga memiliki arti dan fungsi yang penting bagi kelangsungan hidup maupun dalam menemukan makna dan tujuan hidup. Selain itu di dalam keluarga anak didorong untuk menggali, mempelajari, dan menghayati nilai-nilai kemanusiaan, religius, norma-norma (etika), dan pengetahuan (Mulyono, 1995). Berdasarkan pertimbangan segi esensial arti dan fungsi keluarga, dapat dikatakan bahwa keluarga merupakan kesatuan yang terkecil di dalam masyarakat tetapi menempati kedudukan yang primer dan fundamental. Oleh karena itu keluarga mempunyai peranan yang vital dan besar dalam mempengaruhi kehidupan seorang anak.

Perceraian merupakan perpisahan secara resmi antara pasangan suami istri dan tidak lagi menjalankan tugas dan kewajiban sebagai suami istri (dariyo, 2004). 
Peceraian akan menjadi pilihan para pasangan saat masalah yang tidak dapat terselesaikan sehingga nantinya tidak ada permasalahan yang berkelanjutan. Perceraian menyebabkan perubahan struktur dalam keluarga dan tidak hanya berdampak bagi suami-istri saja, namun juga melibatkan anak khususnya yang memasuki usia remaja (Untari, Ida Putri, Kanissa Puspa Dhini Hafiduddin, Muhammad, 2018).

Adanya perceraian menimbulkan kekecewaan anak pada orangtua yang menyebabkan anak menjadi mudah marah dan menjadi tertutup. Kemarahan yang ditimbulkan oleh sejumlah situasi yang merangsang remaja seperti ancaman agresi lahiriah, pengekangan diri, serangan lisan, kekecewaan atau frustasi (Buss \& Perry, 1992). Perasaan yang dialami anak seperti rasa cemas, marah, dan risau membuatnya mengikuti pertengkaran antara ayah dengan ibunya hingga akhirnya membuat mereka tidak tahu harus memihak kepada siapa. Batin mereka menjadi sangat tertekan, sangat menderita, dan merasa malu akibat ulah orangtua mereka. Ada perasaan ikut bersalah dan berdosa, serta merasa malu terhadap lingkungan.

Beberapa dampak yang ditimbulkan baik dari sisi kesehatan, psikologis, maupun akademis. Dampak psikologis seperti dampak psikomotor, dampak kognitif, maupun dampak emosi. Dampak kognisi yang terjadi pada anak, mereka bisa menganggap buruk tentang sebuah perceraian, menganggap bahwa perceraian adalah kesalahan orang tua, dan merasa kurang perhatian. Dampak emosi berupa kekecewaan atas keputusan orang tua, menjadi mudah marah, dan menjadi tertutup. Sedangkan dampak psikomotor terlihat seperti motivasi yang menurun, tidak bersemangat, atau bahkan tertarik untuk melakukan pelampiasan dalam kekerasan. Akibat dari dampak tersebut remaja akan sulit untuk menerima perceraian orangtuanya (Untari, Ida Putri, Kanissa Puspa Dhini Hafiduddin, Muhammad, 2018).

Dampak perceraian akan lebih berimbas pada anak-anak yang memiliki orangtua bercerai pada usia remaja. Hal ini dikarenakan masa remaja merupakan suatu periode peralihan dari masa kanak-kanak ke masa dewasa. Masa remaja dimulai dari usia 10 atau 13 tahun s/d 18 atau 22 tahun (Sanstrock, 2012). Masa remaja ditandai sebagai masa goncangan yang penuh konflik dan perubahan suasana hati (Sanstrock, 2012).

Masa remaja adalah masa dimana seseorang sedang mengalami saat krisis, sebab ia mau menginjak ke masa dewasa. Dalam masa tersebut, remaja dalam keadaan labil dan emosional (Gunarsa \& Gunarsa, 2000). G. Stanley Hall menyebutkan bahwa masa remaja sebagai periode yang berada dalam dua situasi antara goncangan, penderitaan, asmara, pemberontakan dengan otoritas orang dewasa (Sanstrock 2012). Dengan ciriciri sering dan mulai timbul sikap menantang dan melawan terutama kepada orang terdekat seperti orangtua, guru, dan sebagainya (Yusuf, 2010). Sikap menantang dan melawan kepada orang terdekat dan sebagainya dapat digolongkan sebagai tindakan agresif (Negativisme) menurut Buss dan Durkee (dalam Taganing dan Fortuna, 2008).

Masa remaja cenderung memerlukan kehangatan dan keserasian dalam keluarganya serta membutuhkan dukungan emosional orangtua bila mengalami kekecewaan dalam pergaulannya. Akan tetapi, terkadang orangtua tidak begitu memahami keadaan emosional remaja yang membuat remaja tersebut tidak mendapatkan dukungan emosional yang baik. Kurangnya dukungan emosional yang 
dilakukan dapat berupa kekerasan emosional secara verbal maupuun fisik, hal tersebut dapat mempengaruhi perilaku remaja itu sendiri.

Penelitian yang dilakukan oleh Colorado Adoption Project (2000) pada 398 keluarga angkat dan keluarga biologis di London menemukan hasil bahwa 28\% dari keluarga yang bercerai dengan anak yang berumur 12 tahun setelah perceraian anak-anak ini memiliki lebih banyak masalah perilaku dan emosional (perilaku agresif, kenakalan, depresi kecemasan dan penarikan diri), tingkat pencapaian akademis yang rendah serta penyesuaian sosial yang buruk (www.APA.org).

Sementara itu penelitian tersebut didukung oleh fenomena yang terjadi di Indonesia baru-baru ini. Bedasarkan berita yang dimuat oleh Kompas.com (2018), seorang remaja SMA dilaporkan memukul gurunya dengan kursi hanya karena ia ditegur saat ketahuan bermain ponsel di kelas, setelah ditelusuri remaja SMA tersebut merupakan anak dengan orangtua yang bercerai. Serta penelitian yang dilakukan oleh Nisfiannoor (2005) bahwa remaja yang berasal dari keluarga bercerai ternyata lebih agresif bila dibandingkan dengan remaja dari keluarga utuh. Perceraian di antara orangtua ternyata membawa dampak yang negatif bagi anak, terutama dalam berperilaku. Sesuai dengan yang dinyatakan oleh Hetherington (1985) bahwa remaja yang berasal dari keluarga bercerai memiliki masalah dalam berperilaku, terutama dalam perilaku agresifnya.

Menurut Atkinson (dalam Kulsum 2014) agresi diartikan sebagai tingkah laku yang merugikan dan dapat melukai orang lain baik secara fisik maupun verbal. Agresivitas sendiri adalah kecenderungan seseorang untuk melakukan perilaku baik secara fisik atau verbal dengan maksud menyerang orang lain. Sedangkan menurut Buss dan Perry membagi agresi menjadi 4 bagian yakni : Agresi fisik (Phicical Aggression), agresi verbal ( Verbal Aggression), kemarahan (Anger), dan permusuhan (Hostility) (Mu'arifah, 2005).ada pula faktor-faktor yang menyebabkan terjadinya perilaku agresif pada remaja yaitu faktor internal (dari dalam) maupun faktor eksternal (dari luar). Faktor internal tersebut salah satunya: frustasi dan gangguan perasaan/emosional remaja sedangkan faktor eksternal yaitu faktor keluarga (Kartono, 2011). Seperti yang diungkapkan Lerner, Roseser, dan Phelps bahwa sebagian besar remaja mencoba melakukan negosiasi berkaitan dengan waktu yang dibutuhkan untuk akhirnya berhasil menjadi seorang dewasa yang matang namun cukup banyak juga yang tidak berhasil (Santrock, 2012).

Dari penjabaran di atas dapat dilihat bahwa remaja dengan orangtua yang bercerai memiliki kecenderungan yang tinggi untuk melakukan kekerasan pada orang lain. Sementara itu, faktor keluarga yang merupakan salah satu aspek penting yang disinyalir terkait dengan pola perilaku agresif remaja karena sebagian besar masalah remaja saat ini bukanlah pada diri mereka sendiri. Dukungan dari orang dewasa yang mengasihi mereka atau yang dapat disebut dukungan emosional merupakan hal terpenting yang dapat mempengaruhi perkemabangan psikis remaja.

Masa goncangan serta adanya konflik yang dialami oleh remaja berupa perceraian membuat ia membutuhkan dukungan emosional terutama dari orangtua yang merupakan orang terdekat. Dukungan emosional merupakan dukungan untuk memberikan perasaan nyaman, perasaan dicintai dalam bentuk semangat, dan empati yang diperoleh melalui interaksi remaja dengan dengan orang lain dalam lingkungan 
sosialnya, dan bisa berasal dari siapa saja, keluarga, dan teman (Friedman, 2010). Keyakinan yang dimiliki oleh individu bahwa mereka dicintai, diperhatikan, dihargai dan bernilai serta menjadi bagian dalam suatu ikatan sosial juga akan menjadi harta dan sumber pertahanan dalam menghadapi situasi yang sulit (Cobb, dalam Sarafino, 2006). Orangtua merupakan figur yang lekat dengan kehidupan individu, sehingga dukungan orangtua merupakan salah satu sumber dukungan yang dapat memberikan fungsi signifikan dalam hidup individu. Hal tersebut untuk membuatnya merasa aman, memiliki kepastian, merasa dimiliki dan dicintai pada saat mengalami permasalahan.

Penelitian yang dilakukan oleh Anne-Marie Boudreault-Bouchard, et al (2013) menunjukan hasil bahwa dukungan emosional ibu dan ayah memperkuat harga diri dari waktu ke waktu. Penelitian lainnya yang menunjukkan tentang pentingnya dukungan emosional yang baik yang diterima remaja oleh orangtuanya adalah penelitian oleh Vani Wulandari dan Nunung Nurwati (2018) bahwa kekerasan emosional yang dilakukan oleh orangtua baik secara sengaja maupun tidak sengaja dapat mempengaruhi perilaku remaja salah satu dampaknya adalah dapat membuat perilaku remaja menyimpang.

Peran orangtua dibutuhkan agar anak dapat mengontrol emosi positif maupun negatif yang dimilikinya, seperti yang diutarakan oleh Thompson (dalam Santrock, 2012) orangtua adalah pihak yang dapat membantu anak-anak mengatur emosi mereka. Ali dan Asrori (2009) mengemukakan remaja seringkali membangun interaksi sesama teman sebayanya secara khas dengan berkumpul untuk melakukan aktivitas bersama dengan membentuk geng. Kegiatan kumpul bersama yang dilakukan remaja biasanya menstimulasi adanya perilaku agresif baik verbal maupun non verbal. Orangtua yang kurang memberikan perhatian kepada remaja memberikan kontribusi besar pada pembentukan perilaku remaja. Sejalan dengan penelitian yang dilakukan Aroma \& Suminar, (2012) jika seorang remaja yang berasal dari keluarga yang minim dukungan terhadap anak, minim kontrol, dan pengawasan, serta orang tua yang menerapkan pola disiplin secara tidak efektif akan tumbuh menjadi individu dengan kontrol diri lemah dan memiliki kecenderungan untuk terlibat dalam perilaku kenakalan remaja. Namun hal yang disebutkan di atas dapat dihadapi anak dengan baik apabila sebuah sistem dalam keluarga dapat terbangun dengan baik. Adanya perhatian serta dukungan baik dalam bentuk apapun dibutuhkan anak, sehingga anak nantinya akan mendapatkan pengalaman yang baru yang positif disamping perubahan keluarga yang tidak lagi sama dibandingkan dulu. Apa yang dibutuhkan remaja adalah akses terhadap berbagai kesempatan dan dukungan jangka panjang dari orang dewasa yang mengasihi mereka.

Dukungan emosional orangtua merupakan suatu hal yang berkaitan dengan agresivitas yang dimiliki oleh remaja dengan orangtua yang bercerai. Sedangkan agresivitas pada remaja dinilai sebagai sesuatu yang negatif karena dapat mempengaruhi hubungan remaja tersebut dengan keluarga maupun dengan lingkungan sekitar. Perilaku negatif yang mungkin muncul seperti bertindak kasar sehingga menyakiti orang lain, suka berkelahi, mengolok-olok secara berlebihan, membuat kegaduhan dalam masyarakat atau sekolah, mengabaikan perintah, sangat sering berbohong, melanggar peraturan, suka bolos sekolah, suka melanggar kehormatan seks lawan jenis dan seterusnya. Berdasarkan pemaparan di atas, maka 
peneliti tertarik untuk meneliti mengenai keterkaitan antara dukungan emosional orangtua dengan agresivitas remaja dengan orangtua bercerai.

Berdasarkan uraian di atas, dapat dirumuskan masalah penelitian yaitu: Apakah terdapat hubungan antara dukungan emosional orangtua dengan agresivitas remaja dengan orangtua bercerai atau tidak. Tujuan penelitian adalah untuk mengetahui hubungan antara dukungan emosional orangtua dengan agresivitas remaja dengan orangtua bercerai. Penelitian ini penting dilakukan untuk mengetahui hubungan antara dukungan emosional yang diberikan oleh orang tua kepada remaja yang orangtuanya mengalami kasus perceraian sehingga hasil penelitiannya dapat diimplikasikan oleh orangtua kepada remaja terutama yang mengalami kasus perceraian orangtua. Manfaat penelitian yaitu memberikan informasi mengenai bagaimana hubungan dukungan emosional orangtua yang diberikan kepada remaja dan memberikan pemahaman atas makna dari dukungan emosional orangtua yang diterima dan dirasakan oleh remaja. Serta memberikan sumbangan pemikiran dan memperkaya penelitian yang telah ada bagi ilmu psikologi, khususnya bagi Psikologi Perkembangan dan Psikologi Keluarga mengenai dukungan emosional orangtua dan agresivitas remaja dengan orangtua bercerai. Hipotesis pada penelitian ini adalah adanya hubungan negatif antara dukungan emosional orangtua dengan agresivitas remaja dengan orangtua bercerai. Semakin tinggi dukungan emosional yang diberikan orangtua maka semakin rendah agresivitas remaja dengan orangtua bercerai.

\section{METODE}

Penelitian yang akan dilakukan adalah penelitian korelasional dengan pendekatan kuantitatif yang menekankan analisisnya pada data-data numerikal yang diolah dengan metode statistika. Penelitian korelasional bertujuan untuk mengetahui hubungan antara satu variabel dengan variabel lainnya berdasarkan koefisien korelasi (Azwar, 2013). Penelitian yang akan diteliti adalah hubungan antara dukungan emosional orangtua dengan agresivitas remaja dengan orangtua bercerai.

Subjek penelitian ini adalah remaja di Kota Malang. Adapun kriteria sampel yang digunakan dalam penelitian ini yaitu: (1) remaja dengan jenis kelamin laki-laki dan perempuan (2) usia kategori remaja yaitu 12-22 tahun (3) memiliki orangtua yang bercerai (4) tinggal bersama dengan salah satu orangtua.

Teknik sampling yang digunakan dalam penelitian ini adalah Purposive Sampling. Purposive Sampling dikenakan pada sampel yang karakteristiknya sudah ditentukan dan diketahui lebih dulu bedasarkan ciri dan sifat populasinya (Tulus Winarsu, 2015).

Pada penelitian ini terdapat dua variabel, yaitu variabel bebas $(X)$ dan variabel terikat $(Y)$. Adapun variabel bebas $(X)$ adalah dukungan emosional orangtua dan variabel terikat $(\mathrm{Y})$ adalah agresivitas. Dukungan emosional orangtua merupakan ungkapan rasa simpati, pemberian perhatian, kasih sayang, penghargaan dan kebersamaan yang diperoleh individu dari orangtua. Pada aspek penghargaan, bentuknya dapat berupa penghargaan verbal, non verbal serta penghargaan material. Skala variabel ini menggunakan pedoman dari aspek dukungan emosional yang akan disusun peneliti berdasarkan aspek-aspek dukungan emosional menurut Thoits (1986) yaitu ungkapan rasa simpati, perhatian, kasih sayang, penghargaan dan kebersamaan. 
Agresivitas merupakan tingkah laku individu baik secara verbal maupun nonverbal yang bersifat menyerang, menyakiti ataupun merugikan individu lain. Bentukbentuk perilaku seperti rasa marah dan permusuhan masuk dalam perilaku agresif. Adapun Instrumen yang digunakan untuk mengukur variabel ini adalah dengan menggunakan Agression Questionnair (AQ) oleh Buss dan Perry (1992) dengan jumlah item asli sebanyak 29 item.

Tabel 1. Indeks Validitas dan Reliabilitas Alat Ukur Penelitian

\begin{tabular}{lcccc}
\hline \multicolumn{1}{c}{ Alat Ukur } & $\begin{array}{c}\text { Jumlah Item } \\
\text { yang } \\
\text { Diujikan }\end{array}$ & $\begin{array}{c}\text { Jumlah } \\
\text { Item } \\
\text { Valid }\end{array}$ & Indeks Validitas & $\begin{array}{c}\text { Indeks } \\
\text { Reliabilitas }\end{array}$ \\
\hline $\begin{array}{l}\text { Dukungan } \\
\text { emosional orangtua }\end{array}$ & 50 & 38 & $0,336-0,845$ & 0,963 \\
Agresivitas & 29 & 26 & $0,434-0,708$ & 0,927 \\
\hline
\end{tabular}

Berdasarkan uji validitas dan reliabilitas hasil try out yang telah dilakukan terhadap 60 subjek remaja dengan orangtua yang bercerai menunjukkan bahwa alat ukur dukungan emosional orangtua memiliki jumlah item valid sebanyak 38 item dari 50 item yang telah dilakukan uji coba. Selanjutnya alat ukur kecenderungan dukungan emosional orangtua memiliki indeks validitas yang berkisar antara 0,336 - 0,845 dengan indeks reliabilitas sebesar 0,963. Berikutnya alat ukur agresivitas memiliki jumlah item valid sebanyak 26 item dari 29 item yang telah dilakukan uji coba. Selanjutnya alat ukur agresivitas memiliki indeks validitas yang berkisar antara 0,434 0,708 dengan indeks reliabilitas sebesar 0,927. Baik alat ukur dukungan emosional orangtua maupun alat ukur agresivitas keduanya dinyatakan reliabel karena memiliki indeks reliabilitas atau nilai Croanbach Alpha diatas 0,60 (Azwar, 2013).

Penelitian ini menggunakan pendekatan ilmiah yang melewati beberapa tahapan sistematis yang telah disusun dan dapat dipertanggungjawabkan secara ilmiah. Terdapat empat tahapan pada penelitian ini yaitu tahap persiapan, tahap pelaksanaan dan tahap pengolahan data. Pada tahap persiapan, yang dilakukan oleh peneliti adalah melakukan identifikasi permasalahan, menentukan subjek yang akan diteliti, dan alat ukur yang digunakan pada saat penelitian. Selanjutnya peneliti melakukan tahap pelaksanaan yaitu mengurus perizinan, try out, serta melakukan pengumpulan data. Setelah tahap pelaksanaan selesai, dilanjutkan dengan tahap pengolahan data statistik terhadap data yang telah diperoleh. Analisa data dilakukan dengan bantuan perhitungan SPSS for windows Ver. 22 dengan menggunakan teknik analisis Product Moment Pearson karena peneliti ingin mengetahui ada atau tidaknya hubungan antara dua variabel. Kemudian peneliti akan melakukan diskusi data serta memberikan kesimpulan dan implikasi berdasarkan hasil penelitian.

\section{HASIL}

Subjek dalam penelitian ini adalah remaja laki-laki dan perempuan yang berumur 12 tahun hingga 22 tahun yang memiliki orangtua bercerai serta tinggal bersama dengan salah satu orangtua. Total subjek dalam penelitian ini adalah sebanyak 113 orang dengan kriteria yang sesuai. Adapun datanya sebagai berikut: 
Tabel 2. Deskripsi Subjek Penelitian

\begin{tabular}{|c|c|c|}
\hline Kategori Demografis & Frekuensi & Persentase \\
\hline \multicolumn{3}{|l|}{ Jenis Kelamin } \\
\hline Laki-laki & 39 & $34,5 \%$ \\
\hline Perempuan & 74 & $65,5 \%$ \\
\hline Total & 113 & $100 \%$ \\
\hline \multicolumn{3}{|l|}{ Usia } \\
\hline 12-15 tahun & 9 & $8 \%$ \\
\hline 16-19 tahun & 41 & $36,3 \%$ \\
\hline 20-22 tahun & 63 & $55,7 \%$ \\
\hline Total & 113 & $100 \%$ \\
\hline \multicolumn{3}{|l|}{ Tinggal Bersama } \\
\hline Ayah & 30 & $22,6 \%$ \\
\hline Ibu & 83 & $62,4 \%$ \\
\hline Total & 113 & $100 \%$ \\
\hline
\end{tabular}

Mengacu pada tabel 2 dapat diketahui bahwa jumlah subjek yang berjenis kelamin laki-laki lebih sedikit daripada perempuan. Jumlah subjek laki-laki yaitu sebanyak 39 orang atau sebesar 34,5\% sedangkan jumlah subjek perempuan yaitu 74 orang atau sebesar $65,5 \%$. Subjek penelitian terbagi dalam 3 rentang usia, yaitu $12-15$ tahun dengan jumlah 9 orang, 16-19 tahun dengan jumlah 41 orang, kemudian 20-22 tahun dengan jumlah 63 orang. Rentang usia yang mendominasi pada penelitian ini adalah 20-22 tahun dengan persentase 55,7\%. Selanjutnya subjek yang tinggal bersama dengan ayah sebanyak 30 orang atau sebesar 22,6\% dan subjek yang tinggal bersama dengan ibu yaitu 83 orang atau sebesar $62,4 \%$. Jumlah subjek yang tinggal bersama ibu lebih banyak dibandingkan dengan subjek yang tinggal bersama ayah.

Tabel 3. Perhitunan T-skor Dukungan Emosional Orangtua

\begin{tabular}{clcccc}
\hline Kategori & Interval & Frekuensi & Persentase & SD & Mean \\
\hline Tinggi & T-skor $>$ & 57 & $50,4 \%$ & & \\
& 50 & & & 16,3051 & 83,982 \\
\multirow{3}{*}{ Rendah } & T-skor $<$ & 56 & $49,6 \%$ & & \\
& 50 & & & & \\
\hline & Total & $\mathbf{1 1 3}$ & $\mathbf{1 0 0} \%$ & & \\
\hline
\end{tabular}

Mengacu pada tabel 3, dapat diketahui bahwa jumlah subjek dengan kategori tinggi pada dukungan emosional orangtua sebanyak 57 orang atau sebesar 50,4\%. Sedangkan jumlah subjek dengan kategori rendah pada dukungan emosional orangtua sebanyak 56 orang atau sebesar 49,6\%. Sehingga dapat diketahui bahwa subjek dengan kategori dukungan emosional orangtua tinggi lebih banyak daripada subjek dengan kategori dukungan emosional orangtua rendah. 
Tabel 4. Perhitungan T-skor Agresivitas

\begin{tabular}{clcccc}
\hline Kategori & Interval & Frekuensi & Persentase & SD & Mean \\
\hline Tinggi & T-skor $>$ & 49 & $43,4 \%$ & & \\
& 50 & & & 16,8630 & 79,850 \\
\multirow{2}{*}{ Rendah } & $\begin{array}{l}\text { T-skor }< \\
\text { 50 }\end{array}$ & 64 & $56,6 \%$ & & \\
\hline & Total & $\mathbf{1 1 3}$ & $\mathbf{1 0 0} \%$ & & \\
\hline
\end{tabular}

Mengacu pada tabel 4, dapat diketahui bahwa jumlah subjek dengan kategori tinggi terhadap agresivitas sebanyak 49 orang atau sebesar $43,4 \%$. Sedangkan jumlah subjek dengan kategori rendah terhadap dukungan emosional sebanyak 64 orang atau sebesar 56,6\%. Sehingga dapat diketahui bahwa subjek dengan kategori agresivitas rendah lebih banyak daripada subjek dengan kategori agresivitas tinggi.

Tabel 5. Kategorisasi Dukungan Emosional Orangtua dan Agresivitas bedasarkan jenis kelamin

\begin{tabular}{lcccc}
\hline \multicolumn{1}{c}{ Kategori } & \multicolumn{2}{c}{ Dukungan Emosional Orangtua } & \multicolumn{2}{c}{ Agresivitas } \\
\hline \multirow{2}{*}{ Tinggi } & Laki-laki & Perempuan & Laki-laki & Perempuan \\
Rendah & $56,4 \%$ & $60,8 \%$ & $44,9 \%$ & $59,1 \%$ \\
\hline Total & $43,6 \%$ & $39,2 \%$ & $55,1 \%$ & $40,9 \%$ \\
\hline
\end{tabular}

Mengacu pada tabel 5 dapat diketahui bahwa skor dukungan emosional orangtua laki-laki dan perempuan memiliki perbedaan, yaitu skor dukungan emosional orangtua pada remaja perempuan lebih tinggi daripada skor dukungan emosional orangtua pada remaja laki-laki. Berikutnya terdapat perbedaan pula pada skor agresivitas untuk remaja perempuan dan remaja laki-laki, dimana skor agresivitas remaja perempuan lebih tinggi daripada skor agresivitas siswa laki-laki.

Berdasarkan hasil analisa uji normalitas yang telah dilakukan dengan menggunakan SPSS 21, diperoleh hasil probabilitas sebesar 0,132. Nilai tersebut lebih besar dari taraf signifikansi yaitu 0,05, sehingga dapat dinyatakan bahwa data yang diperoleh berdistribusi normal. Dengan mengetahui distribusi data penelitian bersifat normal, maka uji hipotesa penelitian dapat menggunakan analisis statistik parametrik, dimana salah satu syarat uji parametrik adalah data harus berdistribusi normal (Sugiyono, 2015).

Berdasarkan hasil analisa data terhadap 113 subjek dengan menggunakan metode korelasi Product Moment Pearson ditemukan hasil sebagai berikut:

Tabel 6. Hasil Analisa Korelasi Dukungan Emosional Orangtua dan Agresivitas

\section{Koefisien Korelasi}

Koefisien Korelasi (r)

Koefisien Determinasi $\left(r^{2}\right)$

Nilai Signifikansi $(p)$
Indeks Analisis

$-0,327$

0,107

0,000 
Berdasarkan analisa data yang telah dilakukan menggunakan analisa korelasi product moment dari Karl Pearson, diperoleh koefisien korelasi (r) sebesar -0,327 dengan nilai signifikansi $(p)$ sebesar $0,000<0,05$. Hasil ini menunjukkan bahwa terdapat hubungan negatif antara kecenderungan dukungan emosional orangtua dengan agresivitas.

Selanjutnya, mengacu pada hasil analisis data diperoleh nilai koefisien determinasi $\left(\mathrm{r}^{2}\right)$ sebesar 0,107 . Hal ini dapat diartikan bahwa sumbangan efektif dari dukungsn emosional orangtua terhadap agresivitas sebesar $10,7 \%$ dan sisanya, yaitu sebesar $89,3 \%$ ditentukan atau dipengaruhi oleh faktor lain.

\section{DISKUSI}

Berdasarkan penelitian yang telah dilakukan, dapat diketahui bahwa terdapat hubungan negatif yang signifikan antara dukungan emosional orangtua dan agresivitas pada remaja dengan orangtua bercerai. Hal ini didasarkan dari hasil analisa dengan menggunakan uji korelasi product moment pearson, yang menghasilkan nilai koefisien korelasi (r) sebesar $-0,327$ dengan nilai $p$ sebesar $0,00<0,05$. Hal ini dapat dimaknai bahwa semakin tinggi dukungan emosional orangtua yang dialami oleh remaja dengan orangtua bercerai maka semakin rendah pula agresivitas yang dimilikinya, sebaliknya semakin rendah dukungan emosional orangtua yang dialami remaja dengan orangtua bercerai maka semakin tinggi pula agresivitas yang dimilikinya. Hal ini sesuai dengan hipotesis yang telah diajukan oleh peneliti.

Dukungan emosional orangtua memiliki korelasi ke arah negatif dengan agresivitas, sesuai dengan hipotesis yang telah disebutkan peneliti sebelumnya, dimana dukungan emosional orangtua merupakan dukungan untuk memberikan perasaan nyaman, perasaan dicintai dalam bentuk semangat, dan empati yang diperoleh melalui interaksi remaja dengan dengan orang lain dalam lingkungan sosialnya, dan bisa berasal dari siapa saja, keluarga, dan teman (Friedman, 2010). Sedangkan munculnya agresivitas pada remaja dipengaruhi oleh banyak faktor seperti faktor keluarga, sekolah dan lingkungan sekitar (Kurniawati, 2010). Peran orangtua dalam mendampingi anak sebenarnya sangat dibutuhkan ketika anak berada pada masa remaja, sebab pada masa ini anak belajar bagaimana mengambil keputusan yang tepat untuk berperilaku. Peran orangtua dalam mengajarkan remaja mengambil keputusan tidak akan berlangsung efektif jika hubungan orangtua dan remaja tidak berlangsung dengan baik, seperti yang dikatakan Hurlock (2015) bahwa hubungan keluarga berada pada titik terendah ketika anaknya berada dalam masa remaja. masa remaja cenderung memerlukan kehangatan dan keserasian dalam keluarganya serta membutuhkan dukungan emosional orangtua bila mengalami kekecewaan dalam pergaulannya. Akan tetapi, terkadang orangtua tidak begitu memahami keadaan emosional remaja yang membuat remaja tersebut tidak mendapatkan dukungan emosional yang baik.

Dukungan emosional orangtua merupakan faktor yang bersifat sosial, hal ini baik secara langsung atau tidak dapat mempengaruhi keberhasilan seseorang. Orangtua merupakan tokoh yang sangat berperan dalam perkembangan pribadi maupun keberhasilan anak. Menurut Safarino (1990) dukungan emosional merupakan dukungan yang menyebabkan penerima dukungan merasa nyaman tentram kembali, 
merasa dimilki dan dicintai ketika dia mengalami stress, memberi bantuan dalam bentuk semangat, kehangatan personal dan cinta. Dukungan sosial ini merupakan keadaan bermanfaat sehingga individu menjadi tahu bahwa orang lain memperhatikan, menghargai dan mencintai dirinya. Oleh karena itu, hubungan orangtua dan remaja haruslah berjalan harmonis sehingga orangtua dapat belajar memahami apa yang dibutuhkan oleh anaknya yang beranjak dewasa. Jika orangtua salah menanggapi apa yang diharapkan oleh anak, maka anak akan menjauh dari orangtua dan mencari orang lain untuk menjadi tempatnya berkeluh kesah. Orang lain ini belum tentu dapat membawa dampak positif untuk anaknya, sehingga sudah sepatutnya orangtua membangun hubungan yang baik dengan anak. Sesuai dengan penelitian yang dilakukan oleh Jinhong Guo, Sylvie Mrug dan David Knight (2017) menunjukkan bahwa individu dengan orangtua yang mendukung secara emosional melaporkan tingkat yang lebih tinggi dari upaya mobilisasi, yang berarti bahwa individu tersebut dapat melakukan lebih banyak upaya untuk mengatasi stresor. Orang tua yang tidak mendukung secara emosional menghasilkan peningkatan negatif selama tes stres, temuan ini diperkuat pada peserta perempuan Afrika dan Amerika. Adanya dukungan emosional orangtua dapat membantu remaja dalam mengatasi stresor sebagai penyebab munculnya perilaku agresi.

Peran orangtua sebagai manajer sangat dibutuhkan remaja dalam pemilihan teman yang baik. Banyaknya faktor yang dapat menyebabkan individu khususnya remaja melakukan tindakan agresivitas tidak dapat dipungkiri bahwa ternyata dukungan emosional orangtua sangat penting dalam menekan tindakan agresi. Bedasarkan analisis regresi berganda yang telah dilakukan didapatkan koefisien determinasi sebesar 0,107 menunjukkan bahwa kedua variabel bebas memberikan sumbangan efektif sebesar 10,7\% terhadap agresivitas pada diri remaja. Artinya, 10,7\% perilaku agresif pada remaja dengan orangtua bercerai dipengaruhi oleh bagaimana dukungan emosional orangtua yang diterima remaja dan $89,3 \%$ sisanya dipengaruhi oleh faktor lain.

Pada hasil penelitian yang telah dilakukan pada perhitungan T-skor dukungan emosional orangtua dibagi dalam dua kategori rendah dan tinggi dimana kategori tinggi memiliki persentase $50,4 \%$ sedangkan kategori rendah memiliki persentase 49,6\%. Selain itu hasil perhitungan T-skor untuk agresivitas juga dilakukan dengan membaginya dalam dua kategori. Kategori rendah memiliki persentase 43,4\% dan kategori rendah memiliki persentase 56,6\%. Selanjutnya pada perhitungan T-skor agresivitas jumlah subjek dengan kategori tinggi terhadap agresivitas sebanyak 49 orang atau sebesar $43,4 \%$. Sedangkan jumlah subjek dengan kategori rendah terhadap dukungan emosional sebanyak 64 orang atau sebesar 56,6\%. Artinya semakin tinggi skor dukungan emosional yang diterima oleh subjek, maka semakin rendah pula skor agresivitasnya dan begitu sebaliknya.

Adapun beberapa kelemahan pada penelitian ini yaitu penelitian ini hanya berfokus pada tujuan untuk mengetahui korelasi atau hubungan antara kecenderungan dukungan emosional orangtua dengan agresivitas saja, tanpa mampu menjelaskan serta memperkirakan sebab akibat terjadinya hubungan antar dua variabel tersebut. Selanjutnya diperlukan pula perluasan jumlah subjek penelitian serta 
penambahan karakteristik yang berbeda sehingga diharapkan penelitian selanjutnya akan bersifat lebih general dan representatif.

\section{KESIMPULAN}

Bedasarkan hasil penelitian yang dilakukan dapat disimpulkan bahwa hipotesis yang diusulkan peneliti diterima dan terdapat hubungan negatif antara dukungan emosional orangtua dengan agresivitas remaja yang bercerai. Artinya bahwa semakin tinggi dukungan emosional orangtua yang dialami oleh remaja dengan orangtua bercerai maka semakin rendah pula agresivitas yang dimilikinya, sebaliknya semakin rendah dukungan emosional orangtua yang dialami remaja dengan orangtua bercerai maka semakin tinggi pula agresivitas yang dimilikinya.

\section{REFERENSI}

American Psychology Association (APA). (2000). Child of Disvorce. Diakses dari https://www.apa.org/news/press/releases/2000/07/child-of-divorce.aspx

Ali, M \& Asrori, M. (2009). Psikologi remaja. Jakarta: Bumi Aksara.

Azwar, S. (2013). Penyusunan Skala Psikologi. Yogyakarta: Pustaka Pelajar.

Boudreault-Bouchard, A. M., Dion, J., Hains, J., Vandermeerschen, J., Laberge, L., \& Perron, M. (2013). Impact of parental emotional support and coercive control on adolescents' selfesteem and psychological distress: Results of a four-year longitudinal study. Journal of Adolescence, 36(4), 695-704.

Buss, A.H., \& Perry, M. (1992). The Aggression Questionnaire. Journal of Personality and Social Psychology, 63, 452-459.

Chaplin, J.P. (2009). Kamus Lengkap Psikologi. (Terj. Kartono, K). Jakarta: PT. Raja Grafindo Persada.

Dariyo, A. (2004). Memahami Psikologi Perceraian dalam Keluarga. Jurnal Psikologi, Vol 2, No. 2

Dayakisni, Tri., \& Hudaniah. (2012). Psikologi sosial. Malang: UMM Press.

Friedman, M. 2010. Buku Ajar Keperawatan keluarga : Riset, Teori, dan Praktek. Edisi ke-5. Jakarta: EGC

Guo, J., Mrug, S., \& Knight, D. C. (2017). Emotion socialization as a predictor of physiological and psychological responses to stress. Physiology \& Behavior, 175, 119-129.

Hetherington, E. M., Cox, M., \& Cox, R. (1985). Long-Term Effects of Divorce and Remarriage on the Adjustment of Children. Journal of the American Academy of Child Psychiatry, 24(5), 518-530.

Kartono,K. (2011). Psikologi anak. Bandung: Mandar Ma

Kulsum, M. J. (2014). Pengantar Psikologi Sosial. Jakarta: Prestasi Pustaka.

Kurniawati, Y. (2010). Hubungan bermain game online terhadap perilaku agresif remaja. Naskah tidak dipublikasikan, Fakultas Psikologi, Universitas Katolik Soegijapranata, Semarang.

Mu'arifah, A. 2005. Hubungan Kecemasan dan Agresifitas. Yogyakarta. Fakultas. Psikologi Universitas Ahmad Dahlan

Myers, D. G. (2010). Psikologi sosial. edisi 10 buku i. Jakarta: Salemba Humanika.

Nisfiannoor, M. (2005). Perbandingan Perilaku Agresif Antara Remaja Yang Berasal Dari Keluarga Bercerai Dengan Keluarga Utuh. Jurnal Psikologi, Vol.3, No.1

Regional kompas. (2018). Murid yang haja gurunya dengan kursi berasal dari keluara broken home. Diakses dari https://regional.kompas.com/read/2018/03/10/06382121/murid-yang-hajargurunya-dengan-kursi-berasal-dari-keluarga-broken-home

Sanstrock. J,W. (2012). Life Span Development. Edisi ke-13 jilid I: Penerbit Erlangga 


\section{Cognicia}

http://ejournal.umm.ac.id/index.php/cognicia

Sarafino, E. P. (2007). Health psychology biopsychosocial interactions (ed. 6). Canada : John Milley and Sons Inc.

Sugiyono. (2015). Metode Penelitian Kuantitatif Kualitatif R\&B. Bandung: Aflabeta

Untari, I., Putri, K. P. D., \& Hafiduddin, M. (2018). Dampak Perceraian Orang Tua Terhadap Kesehatan Psikologis Remaja. Profesi (Profesional Islam) : Media Publikasi Penelitian, 15(2), 106.

VandenBos, G. R. (ed.). (2007). APA Dictionary of Psychology. Washington DC: American Psychological Association.

Willis, S \& Sofyan. (2005). Remaja dan Masalahnya. Bandung: CV. Alfabeta

Winarsu, Tulus. (2012). Statistik dalam penelitian Psikologi \& Pendidikan. Malang: UMM Press.

Wulandari, Vani,. Nunung Nurwati. (2018). Hubungan Kekerasan Emosional Yang Dilakukan Oleh Orangtua Terhadap Perilaku Remaja. Prosiding Penelitian \& Pengabdian Masyarakat Universitas Padjajaran. Vol 5, No.2

Yusuf, Syamsu. 2010. Psikologi Perkembangan Anak dan Remaja. Bandung : PT Remaja Rosdakarya. 